\title{
The snake community of Serra do Mendanha, in Rio de Janeiro State, southeastern Brazil: composition, abundance, richness and diversity in areas with different conservation degrees
}

\author{
Pontes, JAL. *, Pontes, RC. and Rocha, CFD. \\ Departamento de Ecologia, Instituto de Biologia Roberto Alcântara Gomes, \\ Universidade do Estado do Rio de Janeiro - UERJ, \\ Rua São Francisco Xavier, 524, Maracanã, CEP 20550-011, Rio de Janeiro, RJ, Brazil \\ *e-mail: pontesjal@hotmail.com
}

Received October 29, 2007 - Accepted February 19, 2008 - Distributed August 31, 2009

(With 6 figures)

\begin{abstract}
We studied and compared parameters of the snake community of the Serra do Mendanha, Rio de Janeiro State, southeastern Brazil $\left(22^{\circ} 48^{\prime}-22^{\circ} 51^{\prime} \mathrm{S}\right.$ and $\left.43^{\circ} 31^{\prime}-43^{\circ} 28^{\prime} \mathrm{W}\right)$, such as: abundance distribution, richness, species diversity and biomass, between forested areas, areas under regeneration and agriculture areas (banana plantations); to obtain information about the natural history and facilitate the development of future research. For capturing the snakes we used: pitfall traps, drift-fences and visual search (diurnal and nocturnal) along four transects for each habitat. The captured snakes were measured with a tape and caliper, weighed with dynamometers and sexed with the use of a catheter. The animals marked (with ventral scales cut) were released for posterior recapture. One individual per species was fixed and deposited at the Museu Nacional, Rio de Janeiro. We undertook an effort of 840 man/hour, and captured a total of 207 snakes belonging to 25 species (Colubridae 80.2\%, Elapidae 12.6\%, Viperidae 6.3\% and Boidae 0.9\%). The most abundant were: Liophis miliaris $(\mathrm{n}=33$ ), Micrurus corallinus and Chironius fuscus (both with $\mathrm{n}=26$ ); the least abundant: Elapomorphus quinquelineatus, Siphlophis compressus and Tropidodryas serra (all with $\mathrm{n}=1$ ). The species that contributed the greatest biomass were Spilotes pullatus (7,925 g), Chironius laevicollis (4,694 g), Liophis miliaris $(3,675 \mathrm{~g})$ and Pseustes sulphureus $(3,050 \mathrm{~g})$; those that contributed the lowest biomass were: Siphlophis compressus, Tropidodryas serra (both with $4 \mathrm{~g}$ ) and Elapomorphus quinquelineatus $(3 \mathrm{~g})$. We found significant differences between the sampled habitats at the Serra do Mendanha (undisturbed forest, secondary forest and banana plantations). The results showed that a great reduction in the abundance, richness, diversity and biomass of the snakes occurs when the native forest is replaced by banana plantations.
\end{abstract}

Keywords: Snake community, snake diversity, forest conservation degree, Atlantic Rainforest, Serra do Mendanha.

\section{A comunidade de serpentes da Serra do Mendanha, Estado do Rio de Janeiro, Sudeste do Brasil: composição, abundância, riqueza e diversidade em áreas com diferentes graus de conservação}

\footnotetext{
Resumo

Estudamos e comparamos parâmetros da comunidade de serpentes da Serra do Mendanha, Estado do Rio de Janeiro, Brasil ( $\left(22^{\circ} 48^{\prime}-22^{\circ} 51^{\prime} \mathrm{S}\right.$ e $\left.43^{\circ} 28^{\prime}-43^{\circ} 31^{\prime} \mathrm{W}\right)$, tais como: distribuição de abundância, riqueza e diversidade de espécies e biomassa total, entre áreas florestadas, áreas em regeneração e áreas agrícolas (bananais); para obter informações sobre a história natural e facilitar o desenvolvimento de futuros estudos. Para a captura dos animais foram usadas armadilhas de queda (pitfalls) com cercas-guia e procura visual (diurna e noturna) ao longo de quatro transectos por ambiente. As serpentes capturadas foram identificadas, medidas com trena e paquímetro, pesadas com dinamômetro e sexadas com uso de cateter. Um exemplar por espécie foi fixado e depositado como material testemunho no Museu Nacional, Rio de Janeiro. Os demais indivíduos coletados foram marcados (com corte de escamas ventrais) e soltos. Empreendemos um esforço de cerca de $840 \mathrm{~h} / \mathrm{homem}$, resultando na captura de 207 serpentes pertencentes a 25 espécies (Colubridae 80,2\%, Elapidae 12,6\%, Viperidae 6,3\% e Boidae 0,9\%). As três espécies mais abundantes foram Liophis miliaris ( $\mathrm{n}=33$ ), Micrurus corallinus e Chironius fuscus (ambas com $\mathrm{n}=26$ ), sendo as três menos abundantes Elapomorphus quinquelineatus, Siphlophis compressus e Tropidodryas serra (todas com n $=1$ ). Contribuíram com a maior biomassa Spilotes pullatus (7.925 g), Chironius laevicollis (4.694 g), Liophis miliaris (3.675 g) e Pseustes
} 
sulphureus $(3.050 \mathrm{~g})$. As que menos contribuíram foram Siphlophis compressus, Tropidodryas serra (ambas com $4 \mathrm{~g}$ ) e Elapomorphus quinquelineatus ( $3 \mathrm{~g}$ ). Encontramos diferenças significativas nos parâmetros estudados entre os três tipos de ambientes amostrados na Serra do Mendanha (mata pouco perturbada, mata secundária e monocultura de bananeiras). Os resultados indicaram uma acentuada redução na abundância, riqueza, diversidade e biomassa de serpentes quando a floresta nativa é substituída pela monocultura de bananeiras.

Palavras-chave: comunidade de serpentes, diversidade de espécies, graus de perturbação, Mata Atlântica, Serra do Mendanha.

\section{Introduction}

The city of Rio de Janeiro (Rio de Janeiro State, southeastern Brazil), one of the most populous (ca. six million people) urban areas in the world, contains within its limits three large Atlantic Rainforest remnants: the Tijuca National Park, the Pedra Branca State Park and the Serra do Mendanha Natural Park. Those three parks confer on Rio de Janeiro one of the world's largest forested areas located within the limits of a large city. Unfortunately, those remnants are all presently under strong pressure of degradation (especially at their borders) and are still poorly known regarding their fauna and flora. The Atlantic Forest of the Serra do Mendanha (Figure 1), has approximately 8,500 ha of area and is one of the main forest remnants protecting the Guanabara Bay hydrographic basin, which is the main source of water for most of the surrounding region, including the city of Rio de Janeiro (Pontes, 2005; Prefeitura da Cidade do Rio de Janeiro, 2000; Rocha et al., 2003; SEMADS, 2001). As for other representative groups of the local flo$\mathrm{ra}$ and fauna, there is reduced information regarding the snake fauna inhabiting the area of Serra do Mendanha (Pontes et al., 2008).

In the present work we studied during 62 months (with an effort of $840 \mathrm{man} /$ hour) the snake fauna of the Serra do Mendanha Natural Park evaluating the species composition, abundance, richness, diversity and biomass of the snake fauna in three main environments within the forest: undisturbed forest, secondary forest and banana plantations.

\section{Material and Methods}

The study was carried out at the Atlantic Rainforest of the Serra do Mendanha $\left(22^{\circ} 48^{\prime}-22^{\circ} 51^{\prime} \mathrm{S}\right.$ and $43^{\circ} 31^{\prime}-43^{\circ} 28^{\prime} \mathrm{W}$ ) (Figure 1), located in Rio de Janeiro State, southeastern Brazil. The region is included within the Atlantic Rainforest Biome and is presently covered with forests with a relatively low level of anthropic disturbances and with secondary forests at different states of regeneration. The climate of the area is wet and hot with a relatively dry winter and rainy summer (Aw). The mean annual temperature in the area varies from 18 to $24{ }^{\circ} \mathrm{C}$ and mean annual rainfall averages 1,200 2,000 $\mathrm{mm}$, with most rain falling from September to March (CLINO, 1996; Nimer, 1989).

Snakes were sampled monthly from April 2002 to July 2007 (totalling 62 months of study) using a combination of methods, including intensive visual searching and

pitfall traps with drift-fences (Heyer et al. 1994; Cechin and Martins, 2000). Sampling was made at three major habitats in the Serra do Mendanha: undisturbed forest, secondary forest, and a disturbed area dominated by banana plantations. Canopy height varies among habitats, being $18-25 \mathrm{~m}$ in the undisturbed forest, ca. $10 \mathrm{~m}$ high in the secondary forest and ca. $4 \mathrm{~m}$ high in the monoculture area. At each of these three habitats a similar sampling effort (approximately 280 hours/man) was employed. Intensive visual searching was carried out monthly during different times of the day and night along four linear transects of $500 \mathrm{~m}$ extension at each of the three habitats, totalling $6 \mathrm{~km}$ of extension sampled each month. In addition, at each habitat three systems of pitfall traps were established. Each pitfall system was composed of a set of four $100 \mathrm{~L}$ gallons placed ten metres apart from each other along a straight line. At each habitat, 12 gallons were settled, totalling 36 gallons for the whole area. The gallons of each pitfall system were interconnected with drift fences, totalling $50 \mathrm{~m}$ of drift fences for each system and a total $450 \mathrm{~m}$ of extension for the whole area. The systems remained open during 24 hours from December 2002 to May 2004. Each pitfall trap was checked every two days throughout the month. For each snake captured, its total length (TTL) and snout-vent length (SVL) were taken using measuring tapes (to the nearest $\mathrm{mm}$ ) and Vernier $^{\circledR}$ calipers (to the nearest $0.2 \mathrm{~mm}$ ) and its mass was taken using a Pesola ${ }^{\circledR}$ dynamometer (to the nearest g). The sex of each individual was recorded, with the use of a catheter introduced in the cloaca. The snakes were marked with ventral scales cut (Figure 2) and released for posterior recapture. The altitude (in metrer a.s.l) and the microhabitat used by each snake at the time it was first sighted were also registered. For each habitat (undisturbed forest, secondary forest and banana plantations) the trunk diameter at breast height (DBH) of trees contained within each of six $10 \times 10 \mathrm{~m}$ plots was measured using a measuring tape (to the nearest $1 \mathrm{~mm}$ ) (Rangel and Velàzquez, 1997), with DBH values $\leq 5 \mathrm{~cm}$ not being considered (Botrel et al., 2002). At each habitat the depth of the leaf litter was measured using Vernier ${ }^{\circledR}$ calipers (to the nearest $0.2 \mathrm{~mm}$ ) at 200 points taken at random, keeping a minimum distance of $15 \mathrm{~m}$ between points, and at least $2 \mathrm{~m}$ away from trails. Photographs were taken of all captured specimens. Representative specimens of each species were fixed in $10 \%$ formalin and posteriorly 

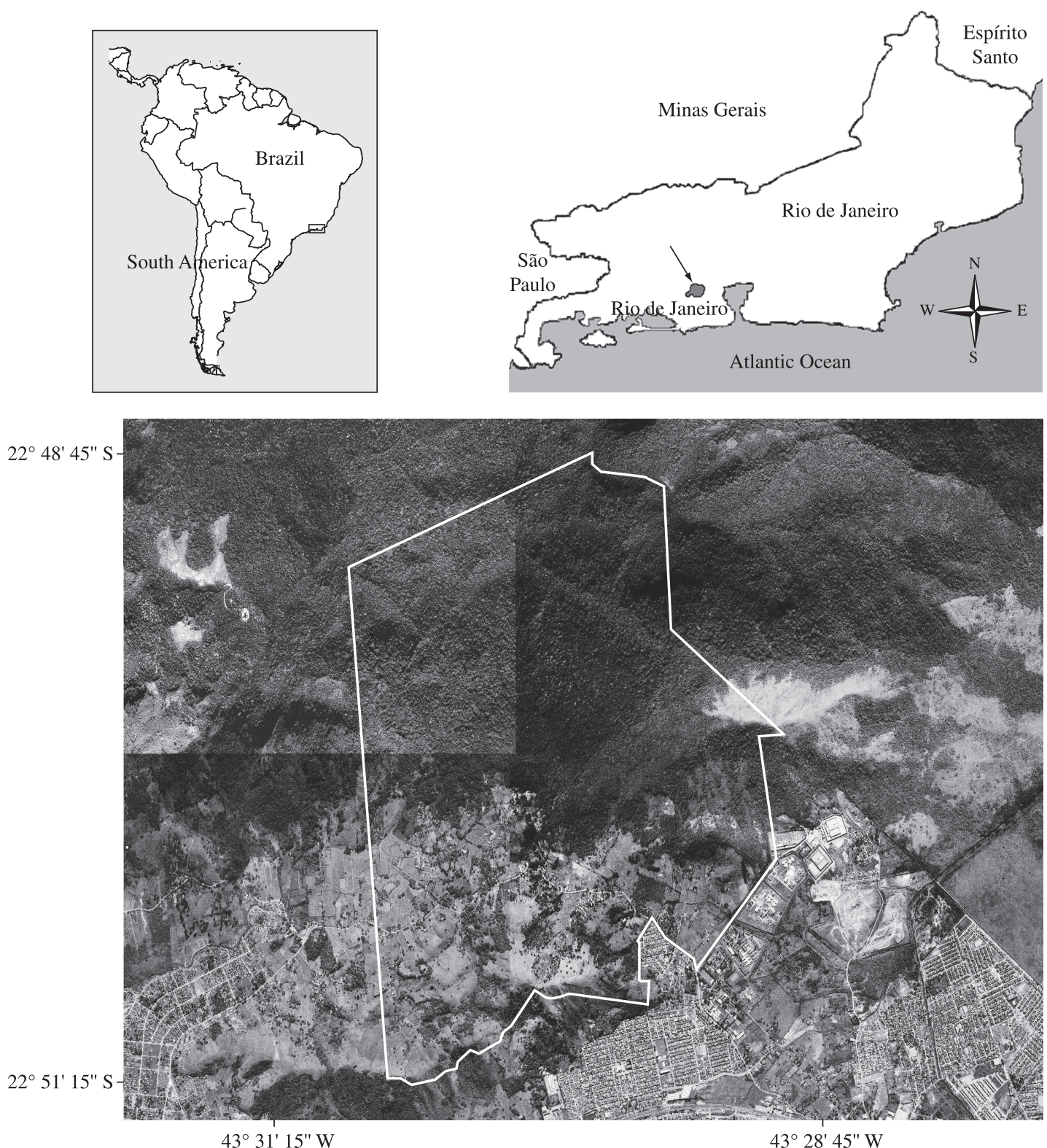

Figure 1. Location of the study area of Serra do Mendanha and limits of the Serra do Mendanha Natural Park in Rio de Janeiro State, southeastern Brazil.

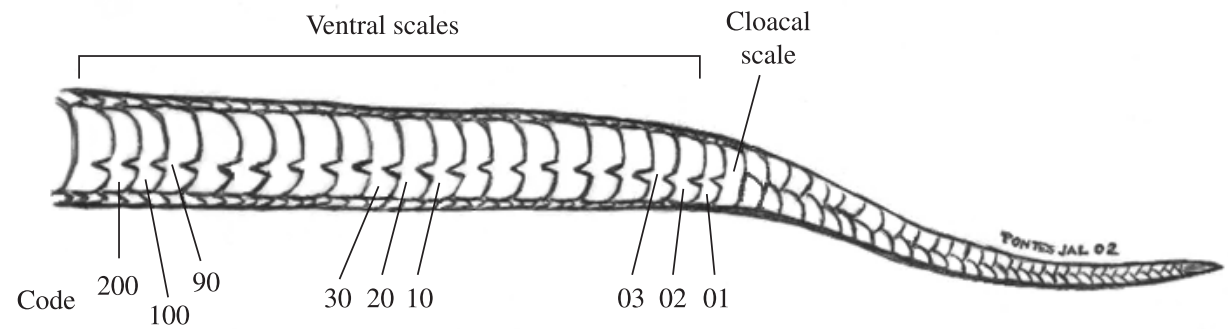

Figure 2. Diagram of ventral scales cut utilised for marking snakes of the Serra do Mendanha, Rio de Janeiro State, southeastern Brazil. 
deposited as voucher specimens at the Museu Nacional, Rio de Janeiro (MNRJ).

Snakes were identified with the aid of published keys (Campbell and Lamar, 2004; Dixon et al., 1993; Franco and Ferreira, 2002; Peters and Orejas-Miranda, 1970; Vanzolini et al., 1980) and a visual guide for identification of Atlantic Forest snakes (Marques et al. 2001), and their identities were afterwards verified by Ronaldo Fernandes (Curator, Herpetology Section, Vertebrate Department Museu Nacional, Rio de Janeiro) and by Daniel S. Fernandes (Department of Zoology, Universidade Federal do Rio de Janeiro).

For each of the three studied habitats at the Serra do Mendanha, the species composition, richness, diversity and mass of the snake fauna was analysed. Snake species richness was estimated using the Margalef index
(DMg): $(\mathrm{S}-1) / \ln \mathrm{N}$, where $\mathrm{S}$ is the number of recorded snake species and $\mathrm{N}$ the total number of individuals of each species (Magurran, 1988). Qualitative similarity of snake assemblages among habitats was estimated using Jaccard's similarity index $\left[\left(\mathrm{C}_{\mathrm{J}}=\mathrm{J} /(\mathrm{A}+\mathrm{B}-\mathrm{J})\right]\right.$, where $\mathrm{J}$ is the number of species common to habitats " $\mathrm{A}$ " and " $\mathrm{B}$ ", $\mathrm{A}$ is the number of species in habitat " $\mathrm{A}$ " and $\mathrm{B}$ is the number of species in habitat "B" (Magurran, 1988). Differences among habitats in terms of the distribution of snake abundances were tested using a Chi-Square test (Zar, 1999) and differences in mean snake mass among habitats was tested by one-way ANOVA (Zar, 1999). The species heterogeneity at each habitat was calculated using Shannon-Wiener diversity index $\left(\mathrm{H}^{\prime}=-\Sigma\right.$ pi ln pi, where pi is the relative abundance of snake species "i" (Magurran, 1988).

Table 1. Snake species in three environments studied (UF = undisturbed forest; SF = secondary forest; $\mathrm{BP}=$ banana plantation $)$ and habits $(\mathrm{Aq}=$ aquatic $; \mathrm{Sa}=$ semi-aquatic $; \mathrm{Fo}=$ fossorial $; \mathrm{Cr}=$ cryptozoic $; \mathrm{Te}=$ terrestrial $; \mathrm{Sar}=$ semi-arboreal $; \mathrm{Ar}=$ arboreal). Serra do Mendanha, Rio de Janeiro, RJ, Brazil.

\begin{tabular}{|c|c|c|c|c|c|c|c|c|c|c|}
\hline \multirow[t]{2}{*}{ Species } & \multicolumn{3}{|c|}{ Environment } & \multicolumn{7}{|c|}{ Habits } \\
\hline & UF & SF & BP & Aq & Sa & Fo & Te & $\mathrm{Cr}$ & Sar & Ar \\
\hline \multicolumn{11}{|l|}{ BOIDAE } \\
\hline Boa constrcitor Linnaeus, 1758 & - & $\mathrm{x}$ & - & - & - & - & $\mathrm{x}$ & - & $\mathrm{x}$ & $\mathrm{x}$ \\
\hline \multicolumn{11}{|l|}{ COLUBRIDAE } \\
\hline Chironius bicarinatus (Wied, 1820) & - & $\mathrm{x}$ & - & - & - & - & $\mathrm{x}$ & - & $\mathrm{x}$ & $\mathrm{x}$ \\
\hline Chironius exoletus (Linnaeus, 1758) & - & $\mathrm{x}$ & - & - & - & - & $\mathrm{x}$ & - & $\mathrm{x}$ & $\mathrm{x}$ \\
\hline Chironius fuscus (Linnaeus, 1758) & $\mathrm{x}$ & $\mathrm{x}$ & - & - & $\mathrm{x}$ & - & $\mathrm{x}$ & - & $\mathrm{x}$ & - \\
\hline Chironius laevicollis (Wied, 1824) & - & $\mathrm{x}$ & - & - & - & - & $\mathrm{x}$ & - & - & $\mathrm{x}$ \\
\hline Chironius multiventris Smith e Walker, 1943 & - & $\mathrm{x}$ & - & - & - & - & $\mathrm{x}$ & - & $\mathrm{x}$ & $\mathrm{x}$ \\
\hline Echinanthera affinis (Günther, 1858) & - & $\mathrm{x}$ & - & - & - & - & $\mathrm{x}$ & $\mathrm{x}$ & - & - \\
\hline Echinanthera cephalostriata Di Bernardo, 1996 & $\mathrm{x}$ & $\mathrm{x}$ & - & - & - & - & $\mathrm{x}$ & $\mathrm{x}$ & - & - \\
\hline Elapomorphus quinquelineatus (Raddi, 1820) & - & $\mathrm{x}$ & - & - & - & $\mathrm{x}$ & $\mathrm{x}$ & - & - & - \\
\hline Helicops carinicaudus (Wied, 1825) & - & $\mathrm{x}$ & - & $\mathrm{x}$ & $\mathrm{x}$ & - & - & - & - & - \\
\hline Leptophis ahaetulla (Linnaeus, 1758) & - & $\mathrm{x}$ & - & - & - & - & - & - & $\mathrm{x}$ & $\mathrm{x}$ \\
\hline Liophis miliaris (Linnaeus, 1758) & - & $\mathrm{x}$ & - & $\mathrm{x}$ & $\mathrm{x}$ & - & - & - & $\mathrm{x}$ & - \\
\hline Liophis poecilogyrus (Wied, 1835) & - & $\mathrm{x}$ & - & - & - & - & $\mathrm{x}$ & - & - & - \\
\hline Oxyhropus petola (Linnaeus, 1758) & - & $\mathrm{x}$ & - & - & - & - & $\mathrm{x}$ & - & - & - \\
\hline Phillodryas olfersii (Lichtenstein, 1823) & - & $\mathrm{x}$ & - & - & - & - & $\mathrm{x}$ & - & $\mathrm{x}$ & $\mathrm{x}$ \\
\hline Pseustes sulphureus (Wied, 1825) & - & $\mathrm{x}$ & - & - & - & - & - & - & - & $\mathrm{x}$ \\
\hline Siphlophis compressus (Daudin, 1803) & - & $\mathrm{x}$ & - & - & - & - & $\mathrm{x}$ & - & $\mathrm{x}$ & $\mathrm{x}$ \\
\hline Spilotes pullatus (Linnaeus, 1758) & - & $\mathrm{x}$ & - & - & - & - & $\mathrm{x}$ & - & - & $\mathrm{x}$ \\
\hline Thamnodynastes nattereri (Mikan, 1828) & - & $\mathrm{x}$ & - & - & - & - & $\mathrm{x}$ & - & - & - \\
\hline Tropidodryas serra (Schelegel, 1837) & - & $\mathrm{x}$ & - & - & - & - & $\mathrm{x}$ & - & - & - \\
\hline Uromacerina ricardinii (Peracca, 1897) & - & $\mathrm{x}$ & - & - & - & - & $\mathrm{x}$ & - & $\mathrm{x}$ & - \\
\hline Xenodon neuwiedii Günther, 1863 & - & $\mathrm{x}$ & - & - & - & - & $\mathrm{x}$ & - & - & - \\
\hline \multicolumn{11}{|l|}{ ELAPIDAE } \\
\hline Micrurus. corallinus (Merrem, 1820) & - & $\mathrm{x}$ & $\mathrm{x}$ & - & - & $\mathrm{x}$ & $\mathrm{x}$ & - & - & - \\
\hline \multicolumn{11}{|l|}{ VIPERIDAE } \\
\hline Bothrops jararaca (Wied, 1824) & - & $\mathrm{x}$ & - & - & - & - & $\mathrm{x}$ & - & $\mathrm{x}$ & - \\
\hline Bothrops jararacussu Lacerda, 1884 & - & $\mathrm{x}$ & - & - & - & - & $\mathrm{x}$ & - & - & - \\
\hline Total 25 & 2 & 25 & 1 & 2 & 3 & 2 & 21 & 2 & 11 & 10 \\
\hline
\end{tabular}




\section{Results}

The total searching effort employed throughout the study was 840 hour/man, resulting in the capture of 207 individual snakes of 25 species (or a rate of capture of 0.25 snake/h/man). Two additional species (Erythrolamprus aesculapii and Leptodeira annulata) are known to occur in the area based on Institutional records (Pontes et al., 2008) but for the purpose of the present study we considered only those snakes sampled in the field. All snakes were captured during search transects with no captures of snakes in pitfall traps. The snakes sampled belonged to four families (Boidae, Colubridae, Elapidae and Viperidae) (Table 1) and Colubridae was the most speciose family ( 23 species, or $85.2 \%$ of the total), followed by Viperidae ( 2 species, or $7.4 \%$ ), Boidae and Elapidae (one species, or $3.7 \%$, each) (Table 1). In terms of numbers, most individuals captured also belonged to Colubridae ( $80.2 \%$ of the individuals; $\mathrm{n}=166$ ) followed by Elapidae $(12.6 \% ; \mathrm{n}=26)$, Viperidae $(6.3 \%$; $\mathrm{n}=13)$ and Boidae $(0.9 \% ; \mathrm{n}=2)$.

The most abundant species in the snake community of Serra do Mendanha was Liophis miliaris ( $\mathrm{n}=33$ ), followed by Chironius fuscus, Micrurus corallinus (both with $\mathrm{n}=26$ ) and Thamnodynastes nattereri $(\mathrm{n}=22)$. These three species accounted for about $52 \%$ of the total number of snakes sampled. Conversely,
Elapomorphus quinquelineatus, Siphlophis compressus and Tropidodryas serra were the least abundant snakes in the area, each represented by a single individual (Figure 3).

Most of the snake species captured at the Serra do Mendanha had terrestrial habits $(84 \%, \mathrm{n}=21)$, followed by those having semi-arboreal habits $(44 \%, \mathrm{n}=10)$, arboreal habits $(40 \%, \mathrm{n}=10)$, and semi-aquatic habits $(12 \%, \mathrm{n}=3)$, whereas cryptozoic, aquatic and fossorial species were rare $(8 \%, \mathrm{n}=2)$ (Table 1$)$.

In terms of the three major habitats sampled at the Serra do Mendanha (undisturbed forest, secondary forest and disturbed area dominated by banana plantations), the richness of snake species was highest in the secondary forest (13 species; DMg = 3.4) (Table 2). In the undisturbed forest, only two snake species (Echinanthera cephalostriata and Chironius fuscus) were sampled $(\mathrm{DMg}=0.91)$, whereas in the disturbed area, only one snake species (Micrurus corallinus) was recorded $(\mathrm{DMg}=0)$ (Table 2). Similarly, the highest values of species diversity $\left(\mathrm{H}^{\prime}=2.4\right)$, abundance and overall abundance occurred in the secondary forest, followed by those recorded in the undisturbed forest and being lowest in the banana plantation area (Table 2).

The snake species also differed in the total mass sampled, being S. pullatus (7,925 g), C. laevicollis $(4,694 \mathrm{~g})$,

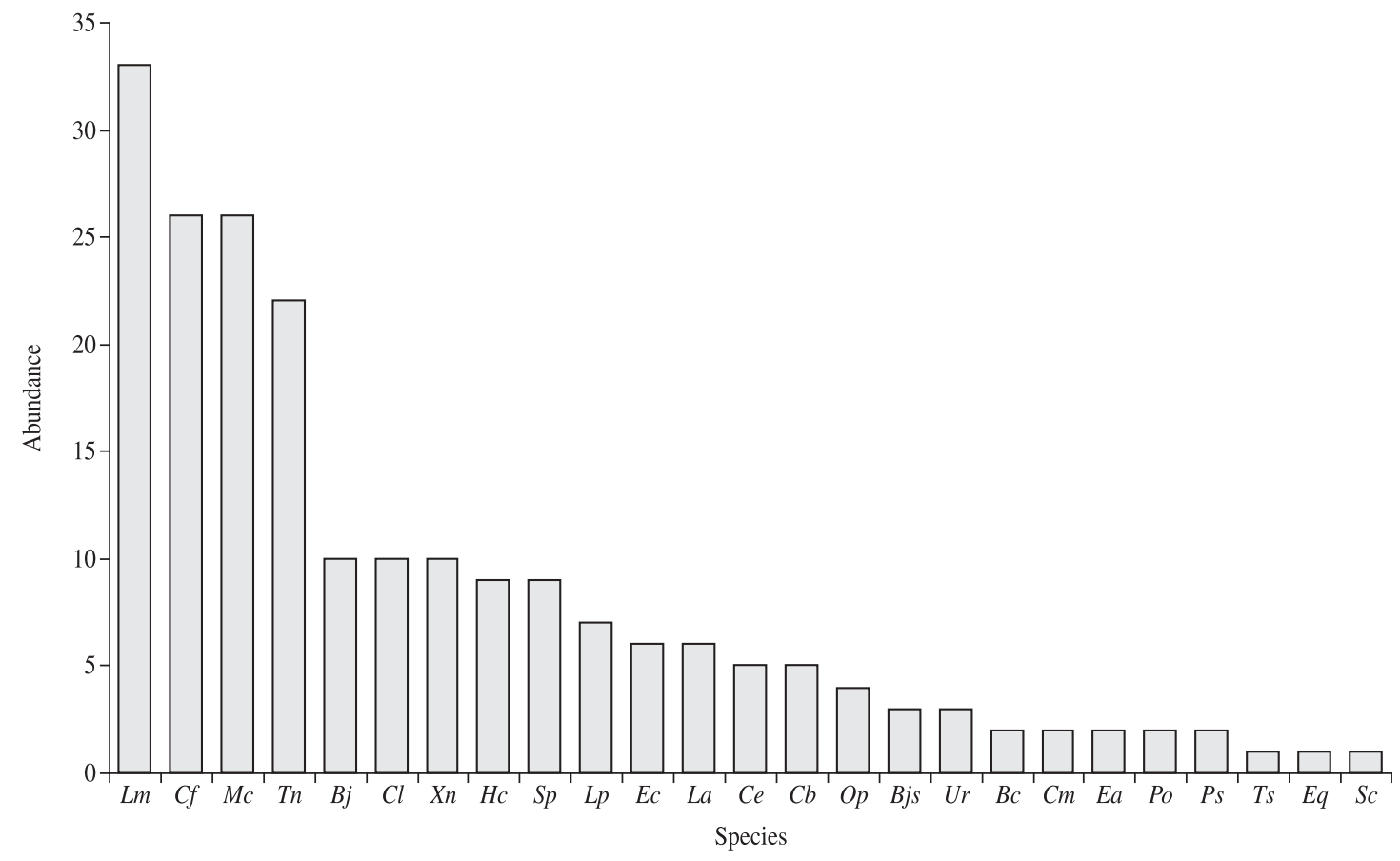

Figure 3. Distribution of abundance for snake species sampled in Serra do Mendanha, Rio de Janeiro State, southeastern Brazil (Lm = Liophis miliaris, $C f=$ Chironius fuscus, Mc $=$ Micrurus corallinus, $T n=$ Thamnodynastes nattereri, Bj $=$ Bothrops jararaca, $\mathrm{Cl}=\mathrm{C}$. laevicollis, $\mathrm{Xn}=$ Xenodon neuwiedii, $\mathrm{Hc}=$ Helicops carinicaudus, $\mathrm{Sp}=$ Spilotes pullatus, $\mathrm{Lp}=$ Liophis poecilogyrus, Ec $=$ Echinanthera cephalostriata, La $=$ Leptophis ahaetulla, $C e=C$. exoletus, Cb $=C$. bicarinatus, $O p=$ Oxyhropus petola, Bjs $=B$. jararacussu, Ur $=$ Uromacerina ricardinii, $B c=$ Boa constrictor, $C m=C$. multiventris, Ea $=$ E. affinis, Po $=$ Philodryas olfersii, $P s=$ Pseustes sulphureus, $T s=$ Tropidodryas serra, Eq = Elapomorphus quinquelineatus, $\mathrm{Sc}=$ Siphlophis compressus). 
Liophis miliaris $(3,675 \mathrm{~g})$ and $P$. sulphureus $(3,050 \mathrm{~g})$ the species presenting the highest total mass in the local snake community. The lowest values of total mass were those of $S$. compressus, $T$. serra (each with $4 \mathrm{~g}$ ) and E. quinquelineatus (3 g) (Figure 4).

The period of the year when most captures of snakes occurred (pooled data for the five years of study) was from October to April, whereas that with the lowest number of captures was from May to September (Figure 5).

The snakes were found in different periods of the day: $41.7 \%$ in the morning $(n=88) ; 48.4 \%$ in the afternoon $(n=100)$ and $4.3 \%$ during the night $(n=9)$. The period with highest number of captures of active snakes ( $\mathrm{n}=134 ; 64.7 \%$ ) was from 10:00 AM to 4:00 PM.

The three major habitats studied differed significantly in the mean depth of the leaf litter with this value being highest for the undisturbed forest $(\overline{\mathrm{x}}=80.8 \pm 20.0 \mathrm{~mm})$, intermediate for the secondary forest $(\overline{\mathrm{x}}=56.2 \pm$ $16.6 \mathrm{~mm})$, and lowest for the disturbed area $(\overline{\mathrm{x}}=34.6 \pm$ $12.3 \mathrm{~mm}$ ) (ANOVA, $\mathrm{F}_{2,597}=389.4 ; \mathrm{p}<0.001, \mathrm{n}=600$ ) (Figure 6). Similarly, the tree trunk diameter (DBH) also differed significantly among the three major habitats, being highest at the undisturbed forest $(\overline{\mathrm{x}}=18.7 \pm 14.6 \mathrm{~cm}$, range 5.1 to $86.3 \mathrm{~cm}, \mathrm{n}=104)$, followed by the secondary forest $(\overline{\mathrm{x}}=16.1 \pm 16.4 \mathrm{~cm}$, range 5.1 to $92.4 \mathrm{~cm}, \mathrm{n}=79)$, and the disturbed area, $\overline{\mathrm{x}}=11.4 \pm 3.7 \mathrm{~cm}$, range 5.1 to $21.0 \mathrm{~cm}, \mathrm{n}=270$ ) (ANOVA, $\mathrm{F}_{2,455}=16.28, \mathrm{p}<0.001$, $\mathrm{n}=458)$.

\section{Discussion}

Our results indicated that most snake species used more than one environment of the Serra do Mendanha with the secondary forest being the environment most

Table 2. Comparison among the three environments studied (UF = undisturbed forest; $\mathrm{SF}=$ secondary forest; $\mathrm{BP}=$ banana plantation) in richness $(\mathrm{DMg}=$ Margalef Index $)$, diversity $\left(\mathrm{H}^{\prime}=\right.$ Shannon-Wiener Index $)$ and similarity $\left(\mathrm{C}_{\mathrm{J}}=\mathrm{Jaccard}\right.$ Index $)$, considered only the snakes captured in transects under similar effort. Serra do Mendanha, Rio de Janeiro, RJ, Brazil.

\begin{tabular}{ccccc}
\hline Environments & Richness $(\mathbf{D M g})$ & Diversity $\left(\mathbf{H}^{\prime}\right)$ & Environment & Similarity $\left(\mathbf{C}_{\mathbf{J}}\right)$ \\
\hline BP & 0 & 0 & $\mathrm{BP} \times \mathrm{UF}$ & 0 \\
UF & 0.91 & 0.64 & $\mathrm{BP} \times \mathrm{SF}$ & 0.08 \\
SF & 3.4 & 2.4 & $\mathrm{SF} \times \mathrm{UF}$ & 0.15 \\
\hline
\end{tabular}

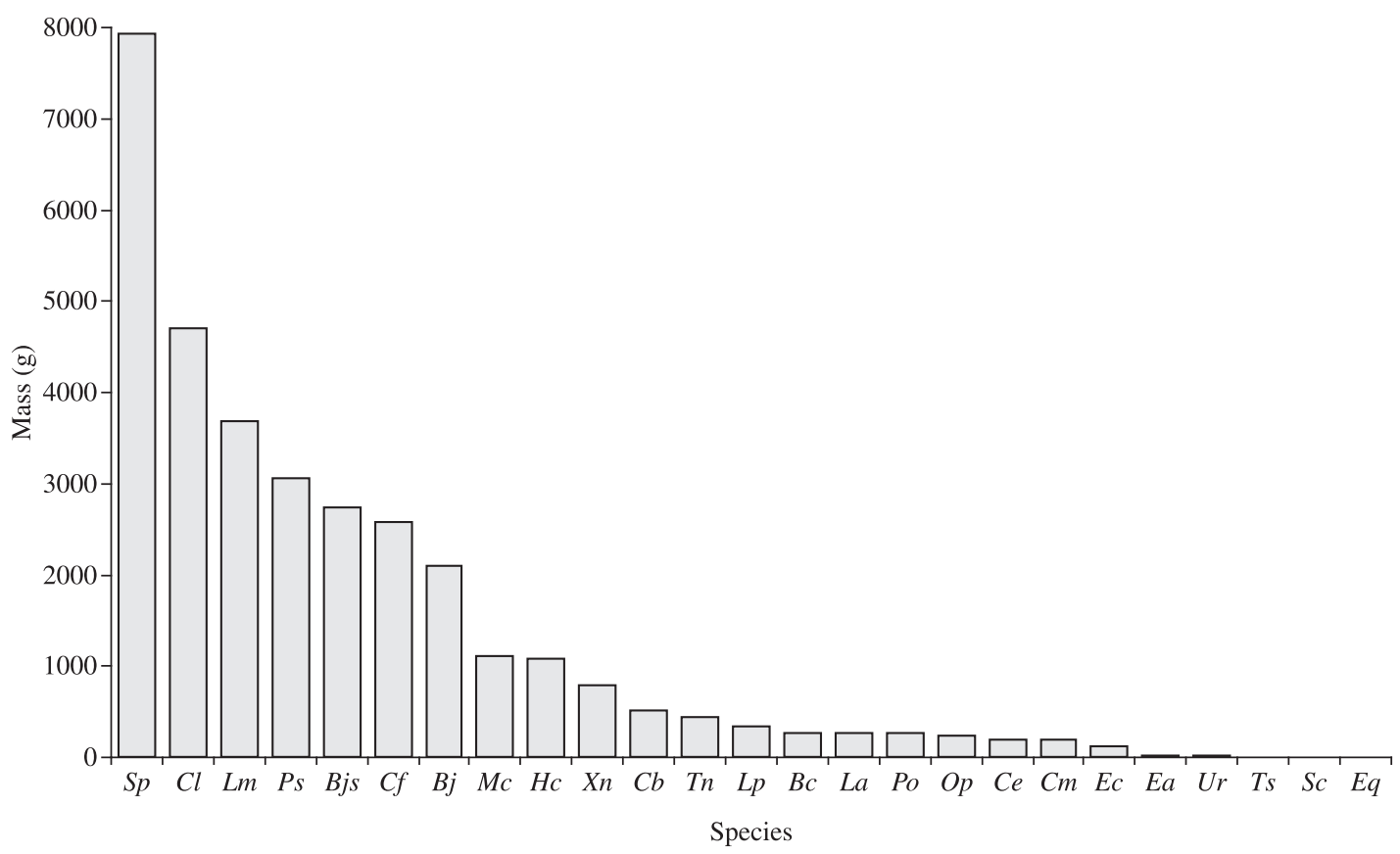

Figure 4. Distribution of accumulate biomass (g) for snake species sampled in Serra do Mendanha, Rio de Janeiro State, southeastern Brazil $(S p=$ Spilotes pullatus, $\mathrm{Cl}=$ Chironius laevicollis, Lm $=$ Liophis miliaris, Ps $=$ Pseustes sulphureus, $B j s=B$. jararacussu, $C f=C$. fuscus, Bj = Bothrops jararaca, $M c=$ Micrurus corallinus, $H c=$ Helicops carinicaudus, Xn $=$ Xenodon neuwiedii, $\mathrm{Cb}=\mathrm{C}$. bicarinatus, Tn = Thamnodynastes nattereri, Lp = Liophis poecilogyrus, Bc $=$ Boa constrictor, La $=$ Leptophis ahaetulla, $P o=$ Philodryas olfersii, $O p=$ Oxyhropus petola,$C e=C$. exoletus, $C m=C$. multiventris, Ec $=$ Echinanthera cephalostriata, Ea $=$ E. affinis, Ur = Uromacerina ricardinii, $T s=$ Tropidodryas serra, $S c=S i p h l o p h i s$ compressus, Eq = Elapomorphus quinquelineatus). 


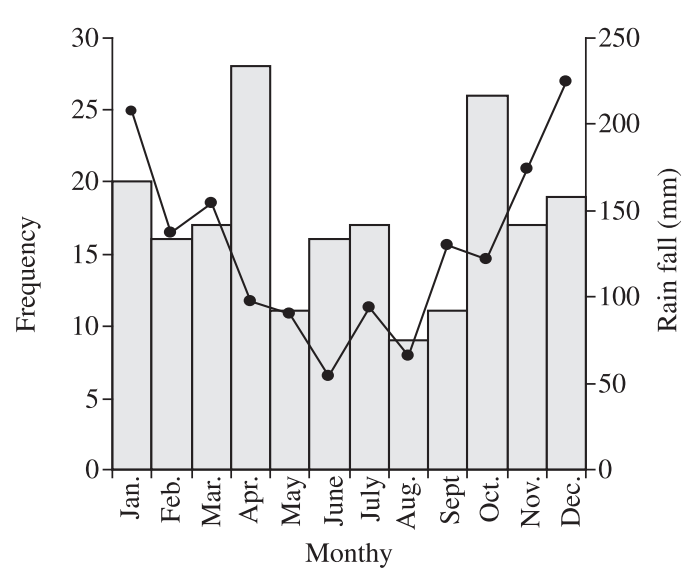

Figure 5. Total number of month encounters with active snakes (gray bars), independent of the species, and rainfall level (mm) (black line) in Serra do Mendanha, Rio de Janeiro State, southeastern Brazil.

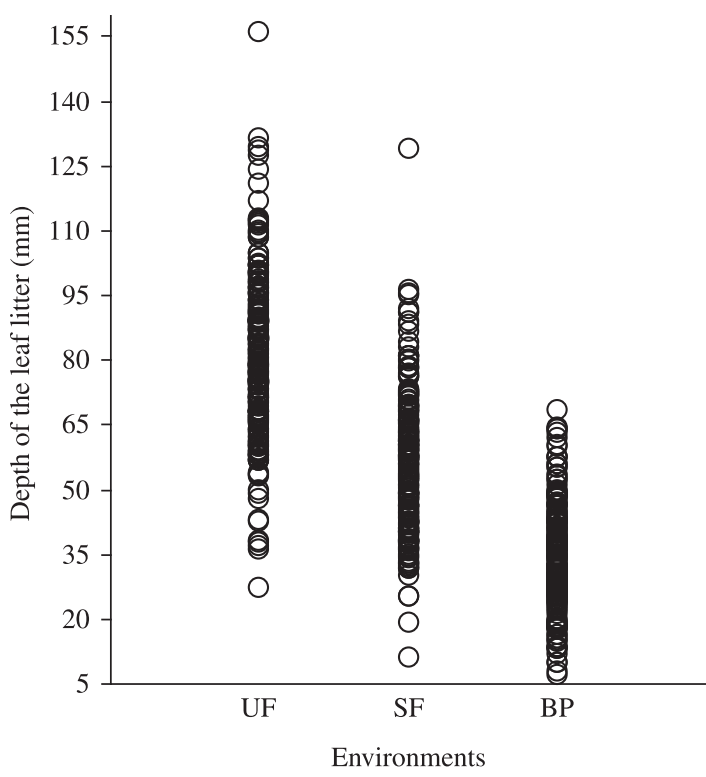

Figure 6. Depth of the leaf litter $(\mathrm{mm})$ in the environments studied $(\mathrm{UF}=$ undisturbed forest; $\mathrm{SF}=$ secondary forest and $\mathrm{BP}=$ banana plantation) in the Serra do Mendanha in Rio de Janeiro State, Southeastern Brazil.

frequently used by snakes in the area. The highest values of snake richness, diversity and biomass in the Serra do Mendanha occurred in the secondary forest, which can be considered an environment with intermediate level of disturbance when compared with the relatively undisturbed forest and with the banana plantation. The larger mean DBH of the trees and the greater depth of the leaf-litter layer in the preserved forest are suggestive of the lower disturbance rate at that environment. The tendency for relatively high richness and/or diversity in environments with intermediate levels of disturbance when compared to well-preserved habitats such as primary tropical forests (with higher homogeneity among habitats) has also been observed for other different groups of organisms (e.g. Connell, 1978; Fonseca, 1989; Stallings et al., 1990; Vera y Conde and Rocha, 2006). However, for snake communities, when the habitat disturbance/degradation level is high (as in agricultural areas), a considerable reduction in diversity, richness and abundance tend to occur (Zug et al., 2001), especially in banana plantations (Marques and Sazima, 2004; Lima et al., 2004; present study). Marques and Sazima (2004) argue that in this type of monoculture there is a reduction of snakes of the genus Chironius, which have a considerable dependence of the structure of the forest. In the present study the occurrence of only one individual of one species (Micrurus corallinus) in the banana plantation area indicates a considerable reduction in species richness and abundance of snakes in this environment at the Serra do Mendanha. These reductions probably result from the alteration of the environment as a consequence of the substitution of the forest by banana monoculture. A decrease in snake richness and abundance in areas having banana plantations was also recorded by Marques (1998) and Marques and Sazima (2004) in some areas near the Estação Ecológica da Juréia-Itatins (a Reserve on the southern coast of São Paulo State). Our data on some parameters of the structural habitat of Serra do Mendanha forest (leaf litter depth and DBH) showed a consistent reduction in the values of these parameters in the banana monoculture area (field observations also suggested a strong loss of herbaceous and arbustive strata, branches and epiphytes). This suggests a loss of those potential microhabitats usually used by different snake species in forested areas for purposes of thermoregulation, foraging and shelter from predators and oviposition sites (Marques, 1998, present study). Additionally, although we did not measure snake prey availability in the environments studied, the differences resulting from habitat alteration in banana plantation may also affect in some way or other the local food availability for the snakes. For example, when a reduction in the density of hylid frogs occurs it may negatively affect the occurrence of snakes of the genus Chironius (Marques, 1998). On the other hand, strongly altered habitats such as banana plantations may favour some snake species which prefer open areas such as Bothrops jararaca (Melgarejo-Giménez, 2003; Marques and Sazima, 2004) and Xenodon neuwiedii (Marques, 1998; Sazima and Haddad, 1992). Liophis miliaris was the most abundant species in the Serra do Mendanha and its abundance may be facilitated by its semi-aquatic habits, as it occupies some microhabitats (rivers, streams, shallow rivulets, swamps and ponds) less used by other snake species (Marques and Souza, 1993; present study).

The most representative snake species of the local community in terms of the total biomass were $S$. pullatus and $C$. laevicollis. The species having the highest total biomass tend to differ among snake assemblages 
(e.g. Eunectes notaeus and Hydrodynastes gigas at the Pantanal area in Poconé - Strüssmann and Sazima, 1993; $C$. bicarinatus and B. jararacussu at the Atlantic rainforest of Casimiro de Abreu - Rocha et al., 2000a) and this seems to reflect the local structure and history of the community, as well as the differences in body size among different snake species. In the Serra do Mendanha the mean mass of most snake species was close to $100 \mathrm{~g}$ (e.g. C. fuscus, L. miliaris, C. multiventris, C. bicarinatus, L. poecilogyrus, L. ahaetulla and $X$. neuwiedii). In the local community the larger snake species (adult body mass higher than $500 \mathrm{~g}$ ) were represented by B. jararacussu, $P$. sulphureus, S. pullatus. and $C$. laevicollis whereas the relatively small snakes (adult body mass lower than $30 \mathrm{~g}$ ) were represented by E. affinis, E. quinquelineatus, $S$. compressus, $T$. nattereri and $U$. ricardinii.

Most snake individuals were found during the diurnal period (mostly from 10:00 AM to 4:00 PM) and this trend seems to reflect the fact that most of the snake assemblage recorded at Serra do Mendanha was composed of diurnal species of the families Colubridae and Elapidae (Di-Bernardo, 1998; Marques et al., 2001), with a marked lack of dipsadines (which are mainly nocturnal) in our samples.

We found an increase in the occurrence of snakes from October to January, a period when the climate is warmer and when most of the rain in the area falls. This seasonal trend in activity has also been recorded for other snake assemblages in South America (e.g. Sazima, 1988; Strüssmann and Sazima, 1993; Di-Bernardo, 1998; Marques, 1998; Sawaya, 2003), and seems to reflect the environmental temperatures and humidity most favorable for snake metabolism and for hatching of eggs and embryo development (Vinegar, 1977; Lillywhite, 1987).

In the snake assemblage of Serra do Mendanha most species were terrestrial and/or semi-arboreal/arboreal, which seems to be the rule in forested (Duellman, 1978; Martins and Oliveira, 1998; Marques, 1998; Freire, 2001; Argôlo, 2004) and open environments (Sawaya, 2003) in South America, whereas in environments dominated by large water bodies, the number of aquatic/semi-aquatic species increases markedly (Strüssmann and Sazima, 1993; Marques et al., 2005).

The loss of species in the banana plantation habitat (only one species was found - the fossorial elapid Micrurus corallinus) seems to reflect the loss of structural features of the habitat that favors snake occurrence (i.e. trees, branches, logs, bromeliads, leaf-litter, fallen trunks and water bodies), as the forest is substituted by banana monoculture.

We conclude that the area of the Serra do Mendanha has a relatively rich snake community (considering that it is located within the limits of a big city) and that the secondary forest tends to have richer, more diverse snake assemblage and a higher snake biomass when compared to the undisturbed forest or the banana plantation.

Acknowledgements - We thank the Secretaria Municipal de Meio Ambiente do Rio de Janeiro for the permits to work at the Parque Natural Municipal da Serra do Mendanha and the Programa de Pós-graduação em Biologia of the Universidade do Estado do Rio de Janeiro - UERJ and the Instituto Biomas for their support. We are also grateful to the park's technicians for assistance during fieldwork and for their help with the installation of the pitfall traps. Davor Vrcibradic kindly reviewed the manuscript offering helpful suggestions. Ronaldo Fernandes (Vertebrate Department, Museu Nacional, Rio de Janeiro) and Daniel S. Fernandes (Zoology Department, Universidade Federal do Rio de Janeiro), verified the identity of the snake specimens. Otavio Marques (Herpetology Laboratory, Instituto Butantan) kindly provided information on snakes deposited at the collection of the Instituto Butantan. The Conselho Nacional do Desenvolvimento Científico e Tecnológico-CNPq, provided grants (Nos. 307653/2003-0 and 477715/2006-0) to CFDR.

\section{References}

ARGÔLO, AJS., 2004. As serpentes dos cacauais do sudeste da Bahia. Ilhéus, Bahia: Editus. 260 p.

BOTREL, RT., OLIVEIRA FILHO, AT., RODRIGUES, LA. and CURI, N., 2002. Influência do solo e topografia sobre as variações da composição florística e estrutura da comunidade arbóreo-arbustiva de uma floresta estacional semidecidual em Ingaí, MG. Revista Brasileira de Botânica, vol. 25, no. 2, p. $195-213$

CAMPBELL, JA. and LAMAR, WW., 2004. The venomous reptiles of the western hemisphere. New York: Cornell University Press. $476 \mathrm{p}$.

CECHIN, SZ. and MARTINS, M., 2000. Eficiência de armadilhas de queda (pitfall traps) em amostragens de anfíbios e répteis no Brasil. Revista Brasileira de Zoologia, vol. 17, no. 3, p. $729-740$.

CLINO., 1996. Climatological Normals (CLINO) for the period 1961-1990. Geneva, Switzerland: World Meteorological Organization. 768 p.

CONNEL, JH., 1978. Diversity in tropical rain forests and coral reefs - high diversity trees and corals is maintained only a non equilibrium state. Science, vol. 199, p. 1302-1310.

DI-BERNARDO, M., 1998. História natural de uma comunidade de serpentes da borda oriental do Planalto das Araucárias, Rio Grande do Sul, Brasil. Rio Claro: Instituto de Biociências, Universidade Estadual de Paulista. 123 p. [Doutorado em Zoologia].

DIXON, JR., WIEST, JA. and CEI, JM., 1993. Revision of the neotropical snake genus Chironius Fitzinger (Serpentes, Colubridae). Torino: Museu Regionale di Scienze Naturali. [Monographie].

DUELLMAN, WE., 1978. The biology of an equatorial herpetofauna in Amazonian Ecuador. Miscellaneous Publication Museum of Natural History University of Kansas, no. 65, p. 1-352.

FONSECA, GAB., 1989. Small mammal species diversity in Brazilian tropical primary and secondary forests of different sizes. Revista Brasileira de Zoologia, vol. 6, p. 381-422.

FRANCO, FL. and FERREIRA, TG., 2002. Descrição de uma nova espécie de Thamnodynastes Wagler, 1830 (Serpentes, Colubridae) do nordeste brasileiro, com comentários sobre o gênero. Phyllomedusa, vol. 1, no. 2, p. 57-74. 
FREIRE, EMX., 2001. Composição, taxonomia, diversidade e considerações zoogeográficas sobre a fauna de lagartos e serpentes de remanescentes da Mata Atlântica do Estado de Alagoas, Brasil. Rio de Janeiro: Museu Nacional, Universidade Federal do Rio de Janeiro. 144 p. [Doutorado em Zoologia].

HEYER, WR., DONNELY, MA., ROY, WM., HAYEK, LC. and FOSTER, MS., 1994. Measuring and monitoring biological diversity. Standard methods for amphibians. Washington and London: Smithsonian Institution Press. 364 p.

LILLYWHITE, HB., 1987. Temperature, energetics and physiological ecology. In: SEIGEL, RA., COLLINS, JT. and NOVAK, SS. (Eds.). Snakes: Ecology and Evolutionary Biology. New York: MacMillan Publ. Co. p. 422-477.

LIMA, DC., CASCON, P. and MELO, JCL., 2004. Análise da influência da bananicultura sobre a herpetofauna nas margens dos riachos da Serra de Maranguape, Estado do Ceará. In: Resumos do I Congresso Brasileiro de Herpetologia. Curitiba, Paraná; [s.n.]. [CD - ROM].

MAGURRAN, A., 1988. Ecological diversity and its measuremen. London: Croom Helm Ltd. 179 p.

MARQUES, OAV., 1998. Composição faunística, história natural e ecologia de serpentes da Mata Atlântica, na região da Estação Ecológica Juréia-Itatins, São Paulo, SP. São Paulo: Instituto de Biociências, USP. 135 p. [Tese de Doutorado].

MARQUES, OAV., ETEROVIC, A. and ENDO, W., 2000. Seasonal activity of snakes in the Atlantic Forest in Southeastern Brazil. Amphibia-Reptilia, vol. 22, p. 103-111.

MARQUES, OAV., ETEROVIC, A. and SAZIMA, I., 2001. Serpentes da Mata Atlântica. Guia ilustrado para a Serra do Mar. Ribeirão Preto: Holos Editora Ltda. 184 p.

MARQUES, OAV., ETEROVIC, A., STRÜSSMANN, C. and SAZIMA, I., 2005. Serpentes do Pantanal. Guia ilustrado. Ribeirão Preto: Holos Editora Ltda. 179 p.

MARQUES, OAV. and SAZIMA, I., 2004. História natural dos répteis da Estação Ecológica Juréia-Itatins. In: MARQUES, AV. and DULEBA, W. (Eds.). Estação Ecológica Juréia-Itatins. Ambiente físico, flora e fauna. Ribeirão Preto: Holos Editora Ltda. p. 257-277.

MARQUES, OAV. and SOUZA, VC., 1993. Notas sobre a atividade alimentar de Liophis miliaris no ambiente marinho (Serpentes, Colubridae). Revista Brasileira de Biologia = Brazilian Journal of Biology, vol. 53, no. 4, p. 645-648.

MARTINS, M. and OLIVEIRA, ME., 1998. Natural history of snakes in forests of the Manaus Region, central Amazônia, Brazil. Herpetological Natural History, vol. 6, no. 2, p. 78-150.

MELGAREJO-GIMÉNEZ, AR., 2003. Serpentes peçonhentas do Brasil. In: CARDOSO, JLC., FRANÇA, FOS., WEN, FH., MÁLAQUE, CMS. and HADDAD Jr, V. Animais peçonhentos no Brasil: biologia, clínica e terapêutica dos acidentes. São Paulo: Sarvier Editora. p. 33-61.

NIMER, E., 1989. Climatologia no Brasil. Rio de Janeiro: IBGE. $421 \mathrm{p}$.

PETERS, JA. and OREJAS-MIRANDA, B., 1970. Catalogue of the neotropical Squamata. Part I: Snakes. United States National Museum Bulletin, vol. 297, p. 1-347.

PONTES, JAL., 2005. A comunidade de serpentes do Parque Natural Municipal da Serra do Mendanha, Rio de Janeiro, RJ: composição, riqueza e diversidade em áreas com diferentes graus de conservação. Rio de Janeiro: Departamento de Ecologia, Instituto de Biologia Roberto Alcântara Gomes, Universidade do Estado do Rio de Janeiro. XI + 188 p. [Unpublished M.Sc. Dissertation].

PONTES, JAL., FIGUEIREDO, JP., PONTES, RC. and ROCHA, CFD., 2008. Snakes from the Atlantic Rainforest area of Serra do Mendanha, in Rio de Janeiro State, Southeastern Brazil: a first approximation to the taxocenosis species composition. Revista Brasileira de Biologia = Brazilian Journal of Biology, vol. 68, no.3, p. 601-609.

PREFEITURA DA CIDADE DO RIO DE JANEIRO., 2000. Mapeamento e caracterização do uso das terras e cobertura vegetal no Município do Rio de Janeiro entre os anos de 1984 e 1999. Rio de janeiro: Secretaria Municipal de Meio Ambiente. $75 \mathrm{p}$.

RANGEL, OJ. and VELÁSQUEZ, A., 1997. Metodos de estudio de la vegetación. In: RANGEL, OJ., LOWY, PD. and AGUIAR, M. Colombia diversidad biotica II: tipos de vegetación en Colombia. Santafé de Bogotá, D.F: Universidad Nacional de Colombia / IDEAM / Ministerio del Meio Ambiente. p. 59-87.

ROCHA, CFD., 1998. Composição e organização da comunidade de répteis da área de Mata Atlântica da região de Linhares, Espírito Santo. In: Anais do VIII Seminário regional de Ecologia. Programa de Pós-Graduação em Ecologia e Recursos Naturais. São Carlos: UFSCar. vol. VIII, p. 869-881.

ROCHA, CFD., LACERDA, P., SARMENTO, A. and MARQUES, AM., 2000a. Introduction to the snake fauna of an area of Atlantic Rainforest in Southeastern Brazil (Casimiro de Abreu - RJ). In: Anais do Simpósio de ecossistemas brasileiros: conservação. São Paulo: Publi. ACIESP. p. 139-146.

ROCHA, CFD., VRCIBRADIC, D. and ARAÚJO, AFB., 2000b. Ecofisiologia de répteis de restingas brasileiras. In: ESTEVES, FA. And LACERDA, LD. (Eds.). Ecologia de restingas e lagoas costeiras. Macaé, Rio de Janeiro: NUPEM / UFRJ. p. 117-149.

ROCHA, CFD., BERGALLO, HG., ALVES, MAS. and SLUYS, MV., 2003. A biodiversidade nos grandes remanescentes florestais do Estado do Rio de Janeiro e nas restingas da Mata Atlântica. São Carlos: RiMa Editora. 146 p.

ROCHA, CFD. and SLUYS, MV., 2006. New records of reptiles from Ilha Grande Island in Rio de Janeiro State, Brazil. Herpetological Review, vol. 37, no. 1, p. 112-114.

SAWAYA, RJ., 2003. História natural e ecologia das serpentes de Cerrado da região de Itirapina, SP. Campinas: Instituto de Biologia, Universidade Estadual de Campinas. 145 p. [Tese de Doutorado].

SAZIMA, I., 1988. Um estudo de biologia comportamental da jararaca, Bothrops jararaca, com uso de marcas naturais. Memórias do Instituto Butantan, vol. 50, no. 3, p. 83-89.

SAZIMA, I. and HADDAD, CFB., 1992. Répteis da Serra do Japi: notas sobre história natural. In: MORELLATO, LPC. (Org.). História Natural da Serra do Japi. Ecologia e preservação de uma área florestal no Sudeste do Brasil. Campinas: Editora da UNICAMP / FAPESP. p. 212-213.

SECRETARIA ESTADUAL DE MEIO AMBIENTE E DESENVOLVIMENTO SUSTENTÁVEL DO RIO DE JANEIRO (SEMADS), 2001. Atlas das Unidades de Conservação da natureza do Estado do Rio de Janeiro. São Paulo: Metavídeo SP Produção e Comunicação Ltda. 48 p. 
STALLINGS, JR., PINTO, LPS., AGUIAR, L. and SÁBATO, EL., 1990. A importância dos distúrbios intermediários na manutenção da diversidade da fauna em uma floresta tropical. In: MARTINS, RP. and LOPES, FS. (Eds.). Atas do Encontro de Ecologia Evolutiva. São Paulo: Academia de Ciências de São Paulo, Publicações ACIESP. vol. 69, p. 43-48.

STRÜSSMANN, C. and SAZIMA, I., 1993. The snakes assembleges of the Pantanal at Poconé, western Brazil: faunal composition and ecology summary. Studies on Neotropical Faunal and Environment, vol. 28, no. 3, p. 157-168.

VANZOLINI, PE., RAMOS-COSTA, AM. and VITT, LJ., 1980. Répteis das Caatingas. Rio de Janeiro: Academia Brasileira de Ciências. $161 \mathrm{p}$.
VERA Y CONDE, CF. and ROCHA, CFD., 2006. Habitat disturbance and the small mammal richness and diversity in an Atlantic Rainforest area in Southeastern Brazil. Revista Brasileira de Biologia = Brazilian Journal of Biology, vol. 66, no. 4, p. 29-41.

VINEGAR, A., 1977. Evolutionary implications of temperature induced anomalies of development on snake embryos. Herpetologica, vol. 30, no.1, p. 72-74.

ZAR, JH., 1999. Biostatistical analysis. 4 ed. New Jersey: Prentice Hall. 663 p.

ZUG, GR., VITT, LJ. and CALDWELL, JP., 2001. Herpetology. An introductory biology of amphibians and reptiles. 2 ed. San Diego, California: Academic Press. 630 p. 